\title{
PGP wt Allele
}

National Cancer Institute

\section{Source}

National Cancer Institute. PGP wt Allele. NCI Thesaurus. Code C111792.

Human PGP wild-type allele is located in the vicinity of $16 \mathrm{p} 13.3$ and is approximately $3 \mathrm{~kb}$ in length. This allele, which encodes phosphoglycolate phosphatase protein, may play a role in the regulation of oxygen transport by red blood cells. 